\title{
Bryological flora of the regional historic Park of Monte Sole (Emilia-Romagna, Italy)
}

\author{
Riccardo Fariselli', Maria Speranza², Michele Aleffi \\ I Via Romea 294, 48015 Savio (RA), Italy 2 Department of Agricultural Sciences, Alma Mater Studiorum \\ University of Bologna, Viale Fanin 44, 40127 Bologna, Italy 3 School of Biosciences and Veterinary Medicine, \\ Bryology Laboratory and Herbarium, University of Camerino, Via Pontoni 5, 62032 Camerino (MC), Italy \\ Corresponding author: Riccardo Fariselli (riccardo_fariselli@libero.it)
}

Academic editor: A. Cogoni | Received 10 March 2017 | Accepted 24 May 2017 | Published 7 June 2017

Citation: Fariselli R, Speranza M, Aleffi M (2017) Bryological flora of the regional historic Park of Monte Sole (EmiliaRomagna, Italy). Italian Botanist 3: 99-108. doi: 10.3897/italianbotanist.3.12663

\begin{abstract}
This article presents the results of a study on the bryological flora of the historic Park of Monte Sole, in the Bologna Apennines (Emilia-Romagna region). A total of 129 taxa were identified, including 9 new findings for the region. The study makes use of the regional cartographic grid, a methodology already used in the description of the vascular flora of the region, applied here for the first time to the bryological flora. If used in future studies, this method will allow a standardization of our knowledge on the distribution of the bryological flora in the region.
\end{abstract}

\section{Keywords}

Flora, Bryophytes, Northern Apennines, Emilia-Romagna, European Floristic Cartographic Grid

\section{Introduction}

In recent years, research on bryophytes in the administrative region of Emilia-Romagna (Italy) has been undergoing a new surge after several years of neglect, thanks also to the publication of the moss flora of Italy (Cortini-Pedrotti 2001, 2005) and, at a European level, of the analytical key for the description of liverworts (Schumacker and Vána 2005).

The first decades of the new millennium have seen two important studies on bryophytes in Emilia-Romagna, one focusing on the Parco dei Gessi bolognesi e Calanchi dell'Abbadessa (Aleffi and Silenzi 2000) and the other on gypsum outcrops 
(Aleffi et al. 2014). The present work concerns the historic Park of Monte Sole and is part of a project aimed to increase our knowledge of the bryological flora of the region. We have also attempted to systematize the presentation of the collected data by reporting our findings on the European floristic cartographic grid usually employed for floristic studies in Emilia-Romagna. Two of the most significant examples of the latter, dealing with vascular flora, include the atlas of protected species of Emilia-Romagna (Alessandrini and Bonafede 1996) and, more recently, the atlas of the ferns of Emilia-Romagna (Bonafede et al. 2016). Our case represents the first attempt to apply this method to the study of the bryological flora, with the aim of collecting and presenting the data in such a way as to be used effectively in subsequent bryological research in Emilia-Romagna and in other territories.

\section{Area of study}

The Park of Monte Sole (Fig. 1) has an extension of just under 6300 ha and is located in the municipalities of Marzabotto, Grizzana Morandi and Monzuno in the Apennines near Bologna. The park is bordered almost entirely, to the east and west, by two water courses: the Reno river to the west, and the Setta, one of its tributaries, to the east. Both water courses converge at the extreme north of the park. The altitude ranges from 90 to $823 \mathrm{~m}$, the highest peak being that of Mount Salvaro. The geology includes various formations, the most substantial being the Loiano sandstones in the eastern, central and southern zones of the park, and the Bismantova Group including sandstone-marl sediments (Pantano formation) and pelitic-sandstone (Cigarello formation) distributed to the north, centre and south of the park (Cazzoli 2003). Less extensive outcrops include the marls of Mount Piano and those of Termina, the Ronzano formation (marl rocks) and that of Antognola (alternation of marl and limestone layers), variously distributed within the park. The soils in the central-northern zone are highly variable in depth; they have a medium texture with good availability of oxygen, and are calcareous and slightly or moderately alkaline (Regione Emilia-Romagna 1994). In the central-eastern zone the soils are characterized by a greater, sometimes considerable, depth, a medium texture, and good availability of oxygen, and are calcareous and moderately alkaline. In the central and southern part they are deep or very deep, with a medium texture and good availability of oxygen; they range from moderately to slightly alkaline both at the surface and deeper down, with a high variability in carbonate content, or are non calcareous, ranging from moderately to highly acid at the surface, to moderately or slightly acidic at greater depth.

According to the phytoclimatic map of Emilia-Romagna, the climate is that of the warm sub-Mediterranean belt (central-Emilian hill landscape; Ubaldi et al. 1996), that is to say with a mean annual temperature between 11.5 and $13^{\circ} \mathrm{C}$ and annual temperature range of $18-22{ }^{\circ} \mathrm{C}$ (sub continental-continental climate). Mean annual precipitation ranges from 800 to $1000 \mathrm{~mm}$ and throughout the region reaches an absolute maximum in autumn and a secondary maximum in spring. There is a xerothermic period in the months of July and August oscillating in 20-year cycles between arid $(\mathrm{P}=2 \mathrm{~T})$ and sub-arid $(\mathrm{P}=3 \mathrm{~T})$ conditions. More precisely, in the period 1991-2005 the weather station of Sasso Marconi, a small town very close to the northernmost portion of the park, recorded a 


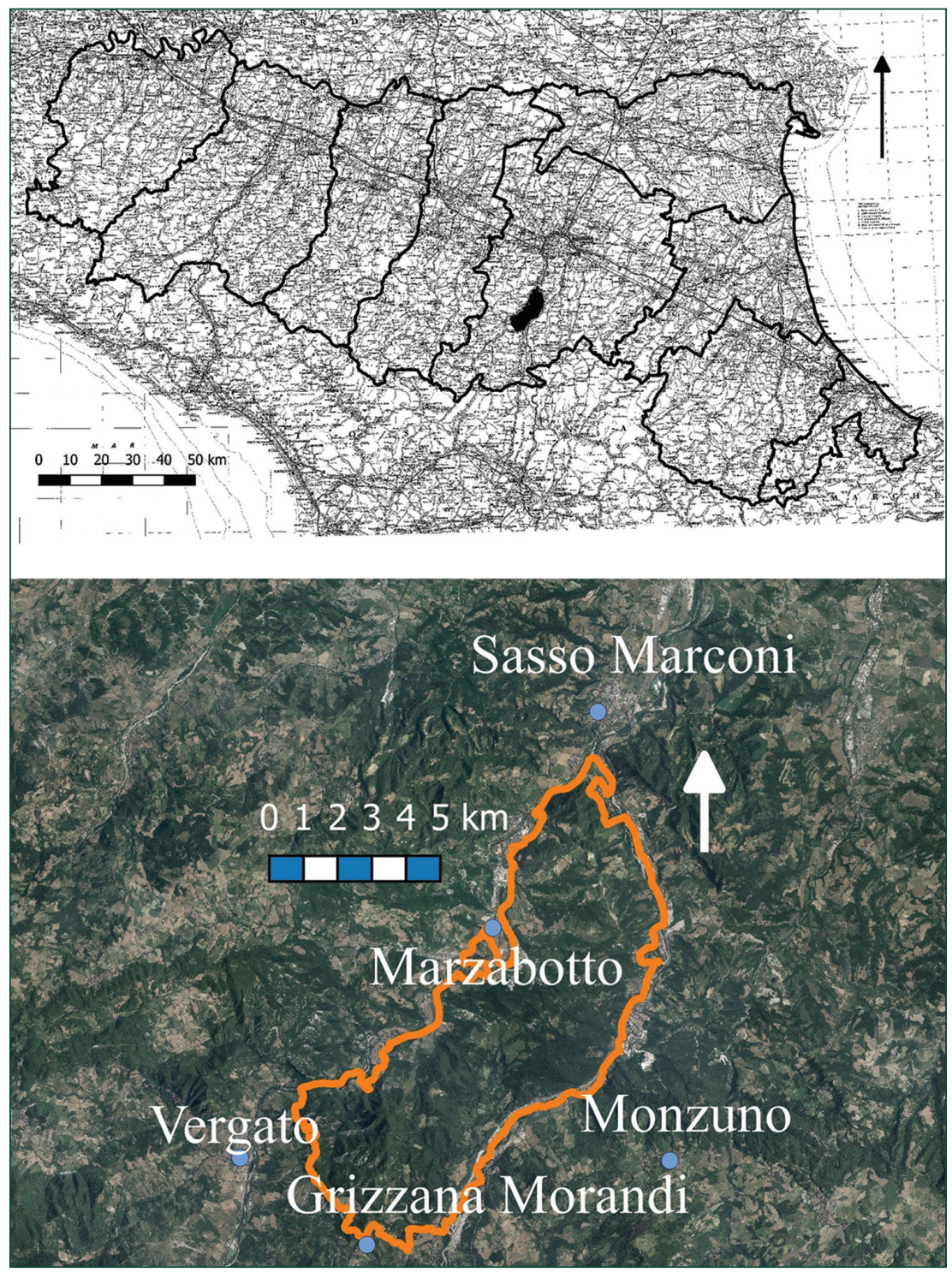

Figure I. The Park of Monte Sole.

mean annual temperature of $14.3^{\circ} \mathrm{C}$, a thermal annual excursion of $20.4^{\circ} \mathrm{C}$ and a mean annual precipitation of $751 \mathrm{~mm}$ (data collected from the ARPA site for Emilia-Romagna: http://www.arpae.it). A period of drought occurs in the month of July. Compared to the data of the phytoclimatic map, the period under examination was characterized by higher temperatures and lower precipitations.

The vegetation consists of woodland with hop-hornbeam and turkey oak belonging to the order Quercetalia pubescenti-petraeae Klika, 1933, which according to a recent classification (Blasi et al. 2004) falls within the alliance Carpinion orientalis Horvat, 1958 , or of woodland with downy oak or downy oak and turkey oak within the same 
alliance (Puppi et al. 1996). Woods of the alliance Erythronio dens-canis-Quercion petraeae Ubaldi, (1988) 1990 are also widespread, consisting of chestnut groves or mixed woods of chestnut with turkey oak, downy oak, durmast oak and aspen. Along the water courses riparian woods of Populetalia albae Br.-Bl. exTchou, 1948 and Salicetalia purpureae Moor, 1958 can be found.

\section{Materials and methods}

The samples were collected from summer 2014 to spring 2016, mostly in early spring, and were kept in the bryological herbarium of one of the authors.

The findings were documented using the cartographic grid adopted in the floristic cartography of Central Europe and also used in Emilia-Romagna, with an interval of $6^{\circ}$ latitude $\times 10^{\circ}$ longitude. As reported in Alessandrini and Bonafede (1996) each area thus derived is called a basic area and is identified by two numbers: the first refers to the row and the second to the column. Each basic area is divided into 4 quadrants indicated by the numbers 1,2, 3 and 4; the quadrant represents the cartographic unit of reference. At the latitudes of Emilia-Romagna, it has mean dimensions of around $6.625 \mathrm{~km}$ longitude $\times 5.550 \mathrm{~km}$ latitude. The Park of Monte Sole lies within columns number 32 and 33 and rows 116 and 117 (Fig. 2). The cartography used for Figures 1 and 2 was taken from the sites of Emilia-Romagna: https://geoportale.regione.emiliaromagna.it and http://ambiente.regione.emilia-romagna.it.

The survey of the territory was not uniform, but concentrated on the areas considered most significant from a bryological point of view. The nomenclature follows Ros et al. (2013) for mosses and Aleffi et al. (2008) for liverworts.

\section{Results}

The list of species identified (Table 1) consists of 129 taxa (17 liverworts and 112 mosses) including nine new findings for the Region (Aleffi et al. 2008): Barbilophozia barbata, Marchesinia mackaii, Pedinophyllum interruptum, Archidium alternifolium, Atrichum angustatum, Fissidens gracilifolius, Gymnostomum viridulum, Schistidium helveticum and Thuidium assimile. In addition, five species were found whose last record dated back to before 1950 (Aleffi et al. 2008): Lophocolea minor, Leptobarbula berica, Mnium lycopodioides, Orthotrichum cupulatum var. cupulatum and Schistidium crassipilum. The asterisk $\left(^{*}\right)$ indicates the new species for Emilia-Romagna. Overall, the species present in the park constitute $24.1 \%$ of the regional flora.

\section{Discussion}

Among the species collected, the finding of Marchesinia mackaii, a southern Atlantic species previously reported in Italy only for Trentino-Alto Adige, Liguria, Toscana, 


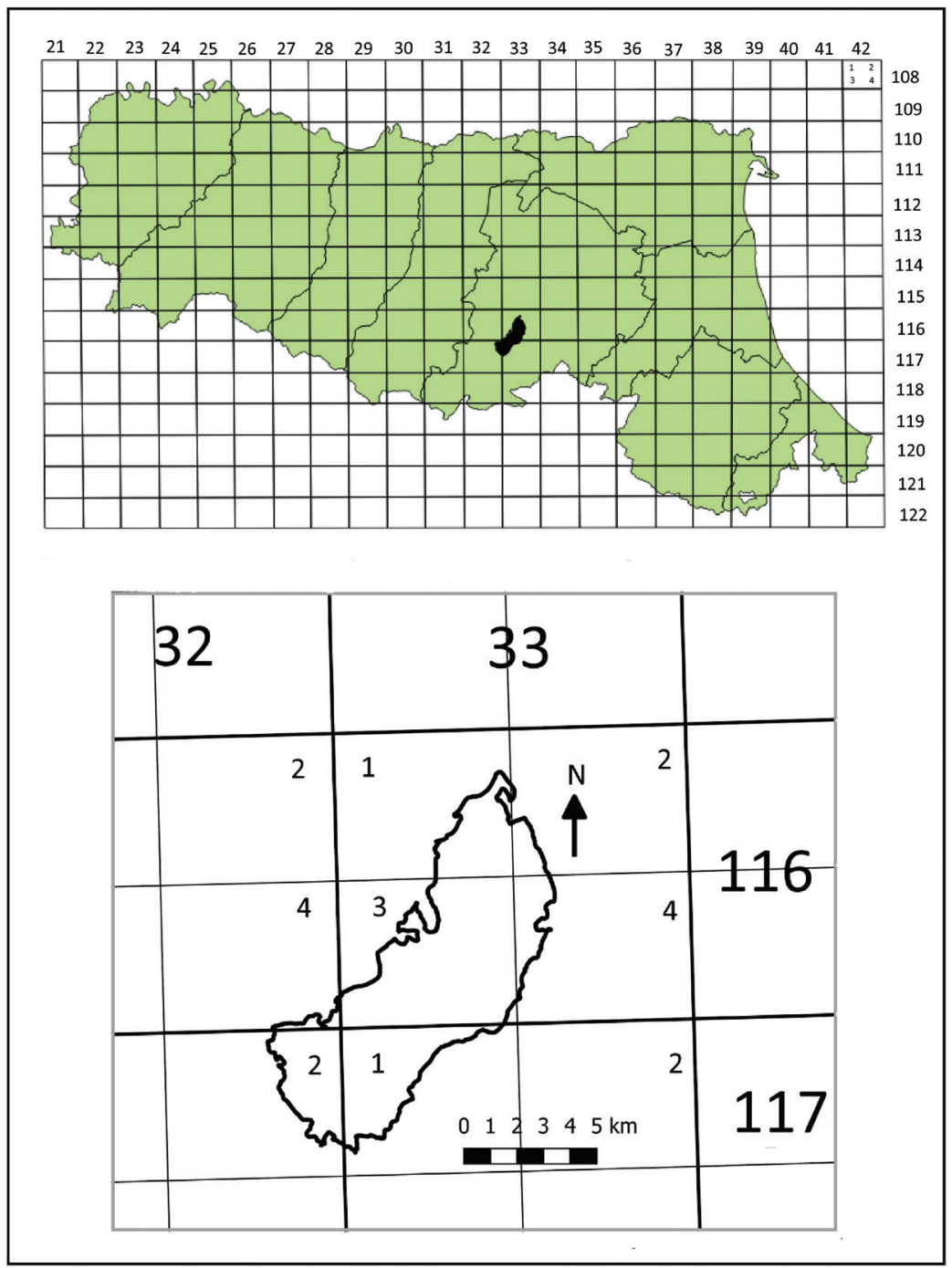

Figure 2. Cartographic grid of the Emilia-Romagna administrative region and, in detail, of the Park of Monte Sole.

Lazio and Campania is particularly interesting (Aleffi et al. 2008). M. mackaii grows primarily on shaded basic rocks, typically on vertical faces within woodland, in colonies of flattened worm-like shoots. Another interesting finding is Fissidens gracilifolius. This temperate-montane species grows directly on limestone rock in a range of wet or dry habitats; it was reported for Trentino-Alto Adige, Toscana, Marche, Abruzzo, Puglia and Sicilia (Aleffi et al. 2008). The finding of Leptobarbula berica is significant since the last record for Emilia-Romagna dates back to a generic report by Fiori (1886). The only recent reports are for Piedmont, Friuli-Venezia Giulia, Campania, Puglia and Sicily. This Mediterranean-Oceanic species forms low lawns or deeper patches on horizontal or sloping silty soils. 
Table I. List of the species identified in the different quadrants.

\begin{tabular}{|c|c|c|c|c|c|c|}
\hline Taxa & 11633-1 & $11633-2$ & $11633-3$ & 11633-4 & 11733-1 & $11732-2$ \\
\hline \multicolumn{7}{|l|}{ Hepatics } \\
\hline *Barbilophozia barbata (Schmidel ex Schreb.) Loeske & & & & & & $\mathrm{x}$ \\
\hline Cephalozia bicuspidata (L.) Dumort. & & & & & $\mathrm{x}$ & \\
\hline Cephaloziella baumgartneri Schiffn. & $\mathrm{x}$ & & $\mathrm{x}$ & & & \\
\hline Frullania dilatata $(\mathrm{L}$.) Dumort. & & & $\mathrm{x}$ & & $\mathrm{x}$ & $\mathrm{x}$ \\
\hline Jungermannia gracillima $\mathrm{Sm}$. & & & & $\mathrm{x}$ & & $\mathrm{x}$ \\
\hline Leiocolea turbinata (Raddi) H. Buch & & & $\mathrm{x}$ & $\mathrm{x}$ & & $\mathrm{x}$ \\
\hline Lejeunea cavifolia (Ehrh.) Lindb. & & & $\mathrm{x}$ & $\mathrm{x}$ & & $\mathrm{x}$ \\
\hline Lophocolea bidentata (L.) Dumort. & & & & & & $\mathrm{x}$ \\
\hline Lophocolea heterophylla (Schrad.) Dumort. & & & $\mathrm{x}$ & $\mathrm{x}$ & $\mathrm{x}$ & $\mathrm{x}$ \\
\hline Lophocolea minor Nees & & & $\mathrm{x}$ & & & $\mathrm{x}$ \\
\hline *Marchesinia mackaii (Hook.) Gray & & & & & & $\mathrm{x}$ \\
\hline Metzgeria furcata (L.) Dumort. & & & $\mathrm{x}$ & & & \\
\hline *Pedinophyllum interruptum (Nees) Kaal. & & & & & & $\mathrm{x}$ \\
\hline Plagiochila porelloides (Torrey ex Nees) Lindenb. & & & & & $\mathrm{x}$ & $\mathrm{x}$ \\
\hline Porella arboris-vitae (With.) Grolle & & & $\mathrm{x}$ & & & \\
\hline Porella platyphylla (L.) Pfeiff. & & & $\mathrm{x}$ & & $\mathrm{x}$ & $\mathrm{x}$ \\
\hline Radula complanata (L.) Dumort. & $\mathrm{x}$ & $\mathrm{x}$ & $\mathrm{x}$ & & $\mathrm{x}$ & $\mathrm{x}$ \\
\hline \multicolumn{7}{|l|}{ Mosses } \\
\hline $\begin{array}{l}\text { Alleniella complanata (Hedw.) S. Olsson, Enroth \& } \\
\text { D. Quandt }\end{array}$ & & & $\mathrm{x}$ & & & \\
\hline Amblystegium serpens (Hedw.) Schimp. & & $\mathrm{x}$ & $\mathrm{x}$ & $\mathrm{x}$ & $\mathrm{x}$ & $\mathrm{x}$ \\
\hline Anomodon viticulosus (Hedw.) Hook. \& Taylor & & $\mathrm{x}$ & $\mathrm{x}$ & & $\mathrm{x}$ & \\
\hline *Archidium alternifolium (Hedw.) Mitt. & & & & & $\mathrm{x}$ & \\
\hline${ }^{*}$ Atrichum angustatum (Brid.) Bruch \& Schimp. & & & $\mathrm{x}$ & & $\mathrm{x}$ & \\
\hline Atricum undulatum (Hedw.) P. Beauv. & & & & & $\mathrm{x}$ & \\
\hline Barbula convoluta Hedw. var. convoluta & & & & & & $\mathrm{x}$ \\
\hline Barbula unguiculata Hedw. & $\mathrm{x}$ & $\mathrm{x}$ & $\mathrm{x}$ & & $\mathrm{x}$ & $\mathrm{x}$ \\
\hline Brachythecium glareosum (Bruch ex Spruce) Schimp. & & & $\mathrm{x}$ & & & $\mathrm{x}$ \\
\hline Brachythecium rivulare Schimp. & & $\mathrm{x}$ & $\mathrm{x}$ & & & $\mathrm{x}$ \\
\hline Brachythecium rutabulum (Hedw.) Schimp. & & $\mathrm{x}$ & $\mathrm{x}$ & $\mathrm{x}$ & $\mathrm{x}$ & $\mathrm{x}$ \\
\hline $\begin{array}{l}\text { Brachythecium salebrosum (Hoffm. ex F. Weber \& D. } \\
\text { Moor) Schimp. }\end{array}$ & & & & & & $\mathrm{x}$ \\
\hline Bryoerythrophyllum recurvirostrum (Hedw.) P.C. Chen & & & $\mathrm{x}$ & & & \\
\hline Bryum dichotomum Hedw. & & $\mathrm{x}$ & & & & $\mathrm{x}$ \\
\hline Bryum radiculosum Brid. & & & & & $\mathrm{x}$ & \\
\hline Calliergonella cuspidata (Hedw.) Loeske & & & & & & $\mathrm{x}$ \\
\hline Campyliadelphus chrysophyllus (Brid.) R.S. Chopra & $\mathrm{x}$ & & $\mathrm{x}$ & $\mathrm{x}$ & $\mathrm{x}$ & $\mathrm{x}$ \\
\hline Campylium stellatum (Hedw.) Lange \& C.E.O. Jensen & $\mathrm{x}$ & $\mathrm{x}$ & $\mathrm{x}$ & & $\mathrm{x}$ & $\mathrm{x}$ \\
\hline $\begin{array}{l}\text { Cirriphyllum crassinervium (Taylor) Loeske } \& \\
\text { M. Fleisch. }\end{array}$ & & & $\mathrm{x}$ & & & $\mathrm{x}$ \\
\hline Cratoneuron filicinum (Hedw.) Spruce & & $\mathrm{x}$ & $\mathrm{x}$ & & $\mathrm{x}$ & \\
\hline Ctenidium molluscum (Hedw.) Mitt. & $\mathrm{x}$ & & $\mathrm{x}$ & $\mathrm{x}$ & $\mathrm{x}$ & $\mathrm{x}$ \\
\hline Dicranella howei Renauld \& Cardot & & $\mathrm{x}$ & $\mathrm{x}$ & & & \\
\hline Dicranella varia (Hedw.) Schimp. & & & & $\mathrm{x}$ & & \\
\hline Dicranum scoparium Hedw. & & & $\mathrm{x}$ & & & \\
\hline Didymodon acutus (Brid.) K. Saito & & & $\mathrm{x}$ & & & \\
\hline Didymodon fallax (Hedw.) R.H. Zander & $\mathrm{x}$ & & & & $\mathrm{x}$ & $\mathrm{x}$ \\
\hline
\end{tabular}




\section{Taxa}

\begin{tabular}{|c|c|c|c|c|c|}
\hline $11633-1$ & $11633-2$ & $11633-3$ & $11633-4$ & $11733-1$ & $11732-2$ \\
\hline
\end{tabular}

Didymodon ferrugineus (Schimp. ex Besch.) M.O. Hill

Didymodon luridus Hornsch.

Didymodon sinuosus (Mitt.) Delogne

Didymodon tophaceus (Brid.) Lisa

Didymodon vinealis (Brid.) R.H. Zander

Ditrichum pusillum (Hedw.) Hampe

Encalypta streptocarpa Hedw.

Encalypta vulgaris Hedw.

Eucladium verticillatum (With.) Bruch \& Schimp.

Eurhynchiastrum pulchellum (Hedw.) Ignatov

\& Huttunen var. pulchellum

Exsertotheca crispa (Hedw.) S. Olsson, Enroth

\& D. Quandt

Fissidens dubius P. Beauv.

*Fissidens gracilifolius Brugg.-Nann. \& Nyholm

Fissidens taxifolius Hedw. subps. taxifolius

Grimmia pulvinata (Hedw.) Sm.

*Gymnostoum viridulum Brid.

Gyroweisia tenuis (Hedw.) Schimp.

Homalothecium lutescens (Hedw.) H. Rob.

Homalothecium sericeum (Hedw.) Schimp.

Hygroamblystegium tenax (Hedw.) Jenn.

Hygrohypnum luridum (Hedw.) Jenn.

Hypnum cupressiforme Hedw. var. cupressifome

Hypnum cupressiforme Hedw. var. filiforme Brid.

Hypnum cupressiforme Hedw. var. lacunosum Brid.

Hypnum cupressiforme Hedw. var. resupinatum

(Taylor) Schimp.

Isopterygiopsis pulchella (Hedw.) Z. Iwats.

Isothecium alopecuroides (Lam. ex Dubois) Isov.

Kindbergia praelonga (Hedw.) Ochyra

Leptobarbula berica (De Not.) Schimp.

Leptodon smithii (Hedw.) F. Weber \& D. Mohr

Leucodon sciuroides (Hedw.) Schwägr.

Microeurhynchium pumilum (Wilson) Ignatov

\& Vanderp.

Mnium lycopodioides Schwägr.

Mnium stellare Hedw.

Orthotrichum affine Schrad. ex Brid.

Orthotrichum anomalum Hedw.

Orthotrichum cupulatum Hoffm. ex Brid.

var. cupulatum

Orthotrichum diaphanum Schrad. ex Brid.

Orthotrichum striatum Hedw.

Orthotrichum tenellum Bruch ex Brid.

Oxyrrhynchium hians (Hedw.) Loeske

Oxyrrhynchium schleicheri (R. Hedw.) Röll.

Oxyrrhynchium speciosum (Brid.) Warnst.

Oxystegus tenuirostris (Hook. \& Taylor) A.J.E. Sm.

Plagiomnium affine (Blandow ex Funck) T.J. Kop.

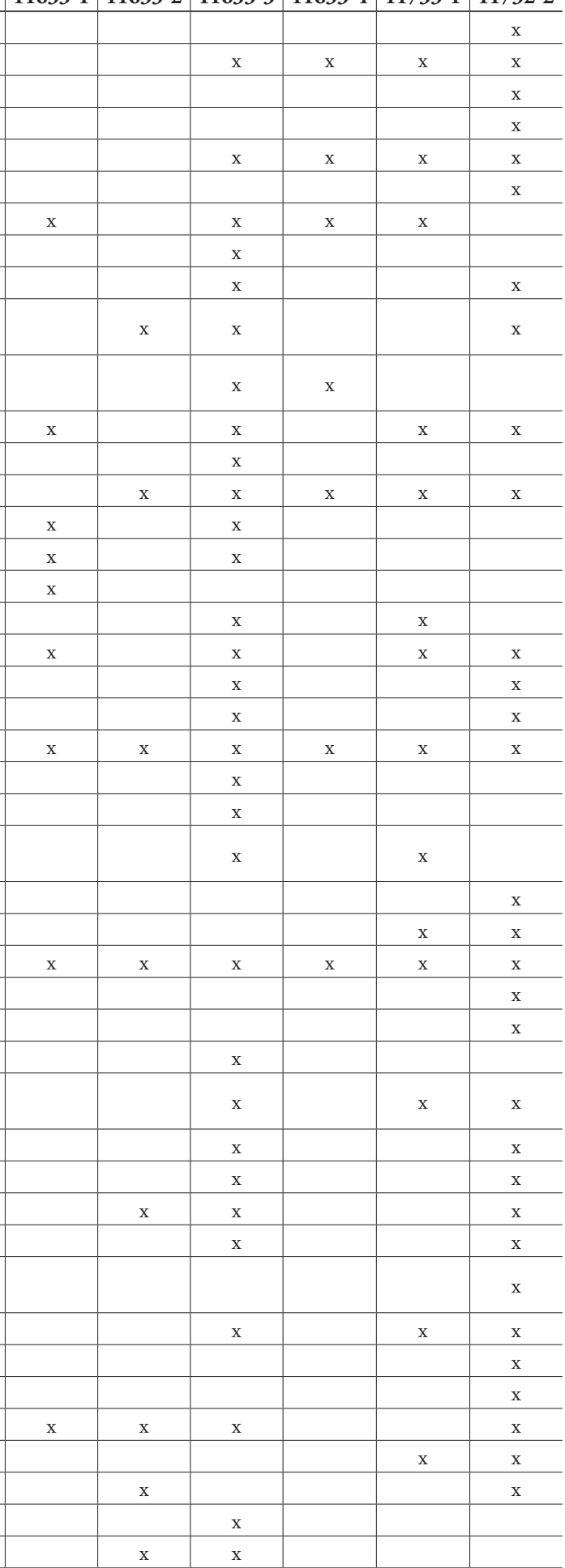




\begin{tabular}{|c|c|c|c|c|c|c|}
\hline Taxa & 11633-1 & $11633-2$ & 11633-3 & $11633-4$ & 11733-1 & $11732-2$ \\
\hline Plagiomnium cuspidatum (Hedw.) T.J. Kop. & & & $\mathrm{x}$ & & & $\mathrm{x}$ \\
\hline Plagiomnium elatum (Bruch \& Schimp.) T.J. Kop. & & & $\mathrm{x}$ & & & \\
\hline Plagiomnium ellipticum (Brid.) T.J. Kop. & & & $\mathrm{x}$ & & & \\
\hline Plagiomnium medium (Bruch \& Schimp.) T.J. Kop. & & & $\mathrm{x}$ & & $\mathrm{x}$ & $\mathrm{x}$ \\
\hline Plagiomnium rostratum (Schrad.) T.J. Kop. & & $\mathrm{x}$ & & & & $\mathrm{x}$ \\
\hline Plagiomnium undulatum (Hedw.) T.J. Kop. & & $\mathrm{x}$ & & & $\mathrm{x}$ & $\mathrm{x}$ \\
\hline Pohlia melanodon (Brid.) A.J. Shaw & & $\mathrm{x}$ & $\mathrm{x}$ & & & $\mathrm{x}$ \\
\hline $\begin{array}{l}\text { Pohlia wahlenbergii (F. Weber \& D. Mohr) } \\
\text { A.L. Andrews }\end{array}$ & & & $\mathrm{x}$ & & & $\mathrm{x}$ \\
\hline Polytrichum formosum Hedw. & & & & & $\mathrm{x}$ & \\
\hline $\begin{array}{l}\text { Pseudoamblystegium subtile (Hedw.) Vanderp. } \\
\text { \& Hedenäs }\end{array}$ & & & $\mathrm{x}$ & & & \\
\hline $\begin{array}{l}\text { Pseudocrossidium hornschuchianum (Schultz) } \\
\text { R.H. Zander }\end{array}$ & & & & & & $\mathrm{x}$ \\
\hline Pseudoleskeella nervosa (Brid.) Nyholm & & $\mathrm{x}$ & & & & $\mathrm{x}$ \\
\hline Pterigynandrum filiforme Hedw. & & & & & $\mathrm{x}$ & \\
\hline $\begin{array}{l}\text { Ptychostomum capillare (Hedw.) Holyoak \& } \\
\text { N. Pedersen }\end{array}$ & $\mathrm{x}$ & & $\mathrm{x}$ & $\mathrm{x}$ & $\mathrm{x}$ & $\mathrm{x}$ \\
\hline $\begin{array}{l}\text { Ptychostomum donianum (Grev.) Holyoak \& } \\
\text { N. Pedersen }\end{array}$ & $\mathrm{x}$ & & $\mathrm{x}$ & & & \\
\hline $\begin{array}{l}\text { Ptychostomum imbricatulum (Müll. Hal.) Holyoak \& } \\
\text { N. Pedersen }\end{array}$ & & & & & & $\mathrm{x}$ \\
\hline Ptychostomum pallens (Sw.) J.R. Spence & & & $\mathrm{x}$ & & $\mathrm{x}$ & \\
\hline $\begin{array}{l}\text { Ptychostomum torquescens (Bruch \& Schimp.) Ros } \& \\
\text { Mazimpaka }\end{array}$ & & & $\mathrm{x}$ & & $\mathrm{x}$ & \\
\hline Rhynchostegiella curviseta (Brid.) Lindb. & & & $\mathrm{x}$ & & & \\
\hline Rhynchostegiella tenella (Dicks.) Limpr. & & $\mathrm{x}$ & $\mathrm{x}$ & $\mathrm{x}$ & & \\
\hline $\begin{array}{l}\text { Rhynchostegium megapolitanum (Blandow ex F. Weber } \\
\text { \& D.Mohr) Schimp. }\end{array}$ & & & $\mathrm{x}$ & & & $\mathrm{x}$ \\
\hline Rhynchostegium riparioides (Hedw.) Cardot & & $\mathrm{x}$ & $\mathrm{x}$ & & & $\mathrm{x}$ \\
\hline Schistidium crassipilum H.H.Blom & & & $\mathrm{x}$ & & & $\mathrm{x}$ \\
\hline${ }^{*}$ Schistidium helveticum (Schkuhr) Deguchi & & & & & & $\mathrm{x}$ \\
\hline Scleropodium touretii (Brid.) L.F. Koch & & & & & $\mathrm{x}$ & \\
\hline Seligeria pusilla (Hedw.) Bruch \& Schimp. & & & $\mathrm{x}$ & & & $\mathrm{x}$ \\
\hline Syntrichia laevipila Brid. & & & & & & $\mathrm{x}$ \\
\hline Syntrichia montana Nees & & & $\mathrm{x}$ & & & \\
\hline $\begin{array}{l}\text { Syntrichia ruralis (Hedw.) F. Weber \& } \\
\text { D. Mohr var. ruralis }\end{array}$ & & & $\mathrm{x}$ & & & \\
\hline${ }^{*}$ Thuidium assimile (Mitt.) A. Jaeger & & & & & & $\mathrm{x}$ \\
\hline Tortella flavovirens (Bruch) Broth. & $\mathrm{x}$ & & & $\mathrm{x}$ & $\mathrm{x}$ & \\
\hline Tortella inclinata (R.Hedw.) Limpr. & & & $\mathrm{x}$ & & & \\
\hline Tortella squarrosa (Brid.) Limpr. & & & $\mathrm{x}$ & & & $\mathrm{x}$ \\
\hline Tortella tortuosa (Hedw.) Limpr. & & & $\mathrm{x}$ & $\mathrm{x}$ & $\mathrm{x}$ & $\mathrm{x}$ \\
\hline Tortula lindbergii Broth. & & $\mathrm{x}$ & $\mathrm{x}$ & & & $\mathrm{x}$ \\
\hline Tortula muralis Hedw. & & & $\mathrm{x}$ & $\mathrm{x}$ & & $\mathrm{x}$ \\
\hline Tortula subulata Hedw. & & & $\mathrm{x}$ & & $\mathrm{x}$ & $\mathrm{x}$ \\
\hline Tortula vahliana (Schultz) Mont. & & & $\mathrm{x}$ & & & \\
\hline Trichostomum brachydontium Bruch & & & $\mathrm{x}$ & & & $\mathrm{x}$ \\
\hline Trichostoum crispulum Bruch & $\mathrm{x}$ & $\mathrm{x}$ & $\mathrm{x}$ & & $\mathrm{x}$ & $\mathrm{x}$ \\
\hline Zygodon rupestris Schimp. ex Lorentz & $\mathrm{x}$ & $\mathrm{x}$ & $\mathrm{x}$ & & $\mathrm{x}$ & \\
\hline
\end{tabular}


The area under investigation contains various different growth habitats for bryophytes. The first of these is the terrain. Here, some characteristic species of the class Barbuletea unguiculatae Mohan, 1978 and order Barbuletalia unguiculatae v. Hübschmann, 1960 were identified, such as Barbula unguiculata, Ptychostomum capillare and Didymodon fallax. Species characteristic of the alliance Grimaldion fragrantis Smarda \& Hadac, 1944 are Didymodon luridus, D. vinealis, Encalypta vulgaris, Tortella squarrosa and Pseudocrossidium hornschuchianum. A second growth habitat for bryophytes are the stations with outcropping rocks, where some characteristic species were observed belonging to the classes Grimmietea anodontis Hadac \& Vondracek in Jaezek \& Vondracek, 1962 and Ctenidietea mollusciv. Hübschmann ex Grgic, 1980, both typical of calcareous substrates. The former class is represented by Tortula muralis, Grimmia pulvinata, Schistidium crassipilum and Schistidium helveticum, while the class Ctenidietea is represented by Ctenidium molluscum, Tortella tortuosa, Encalypta streptocarpa and Fissidens dubius. The epiphytic communities belong to the class Frullanio dilatatae-Leucodontetea sciuroidis Mohan, $1978 \mathrm{em}$. Marstaller, 1985. The characteristic species surveyed in the investigated areas include Frullania dilatata and Radula complanata, as well as Leucodon sciuroides, Orthotrichum affine, O. diaphanum and Zygodon rupestris. The class Neckeretea complanatae Marstaller, 1986 is typical of communities that grow on trunks or basic rocks. The surveyed characteristic species are Homalothecium sericeum, Porella platyphylla and, less frequent but not rare, Mnium stellare and Cirriphyllum crassinervium. Finally, in the humid zones, particularly within the minor water courses where the species may be partially emerged for quite long periods during the dry season, especially in the smaller streams, some characteristics of the class Plathypnidio-Fontinalietea antipyreticae Philippi, 1956, were found, such as Rhynchostegium riparioides, the most common, and, more rarely, Hygrohypnum luridum, Hygroamblystegium tenax, Oxyrrhynchium speciosum; also present are Cratoneuron filcinum (in flowing waters) and Brachythecium rivulare, more at the margins, and in any case in stations ranging from very humid to wet.

\section{Conclusions}

This study not only represents a contribution to the knowledge of the bryological flora of Emilia-Romagna, but also provides results of both floristic and chorological interest. The relatively high number of species found is noteworthy, especially considering the limited extension of the area investigated. Moreover, since our knowledge of the distribution of bryophytes in Emilia-Romagna is extremely incomplete and because the only recently published works all deal with the gypsum outcrops of the region, the study covers an aspect that has not yet fully explored within the territory. The use of the European floristic cartographic grid to present the findings can also open the way to a more standardized description of the distribution data. These, if taken up in future studies, could lead to the creation of a regional database allowing the distribution of the species to be presented in a more homogenous manner, as has already been done in various cases for the vascular flora. 


\section{Acknowledgements}

The authors would like to thank the Ente di Gestione per i Parchi e la Biodiversità dell'Emilia Orientale for authorizing them to carry out the research, with deed n. 140 of 07/07/2014 and deed n. 2 of 11/01/2016.

\section{References}

Aleffi M, Pellis G, Puglisi M (2014) The bryophyte flora of six gypsum outcrops in the Northern Apennines (Nature 2000 Network, Emilia Romagna Region, Italy). Plant Biosystems 148(4): 825-836. https://doi.org/10.1080/11263504.2014.949331

Aleffi M, Silenzi MR (2000) Flora Briologica degli affioramenti gessosi del Parco Regionale "Gessi Bolognesi e Calanchi dell'Abbadessa” Emilia-Romagna. Archivio Geobotanico 6(1): 1-16.

Aleffi M, Tacchi R, Cortini-Pedrotti C (2008) Check-list of the Hornworts, Liverworts and Mosses of Italy. Bocconea 22: 1-256.

Alessandrini A, Bonafede F (1996) Atlante della Flora Protetta della Regione Emilia-Romagna. Regione Emilia-Romagna, Bologna, 365 pp.

Blasi C, Di Pietro R, Filesi L (2004) Syntaxonomical revision of Quercetalia pubescenti-petraeae in the Italian Peninsula. Fitosociologia 41(1): 87-164.

Bonafede F, Vignodelli M, Marchetti D, Alessandrini A (2016) Felci dell'Emilia-Romagna.

Distribuzione, monitoraggio e conservazione. Regione Emilia-Romagna, Bologna, 1-204.

Cazzoli MA (2003) Geologia e geomorfologia. In: Valbonesi E, Palazzini M, Gavioli L, Bedonni

B (Eds) Parco Storico Regionale Monte Sole. Editrice Compositori, Bologna, 85-155.

Cortini-Pedrotti C (2001) Flora dei Muschi d'Italia. Sphagnopsida, Andreaeopsida, Bryopsida (I parte). Antonio Delfino Editore, Roma, 1-832.

Cortini-Pedrotti C (2005) Flora dei Muschi d'Italia. Bryopsida (II parte). Antonio Delfino Editore, Roma, 432 pp.

Fiori A (1886) Muschi del Modenese e del Reggiano. Ia Contribuzione. Atti Soc. Naturalisti Modena Mem. 5: 127-179.

Puppi G, Ubaldi D, Zanotti AL (1996) Carta della vegetazione con itinerari naturalistici 1:25.000 Parco Regionale Monte Sole Contrafforte Pliocenico. Regione Emilia-Romagna: Servizio Cartografico e Geologico. S.E.L.C.A., Firenze.

Regione Emilia-Romagna (1994) I suoli dell'Emilia-Romagna. Note illustrative con carta 1:250.000. Regione Emilia-Romagna, Bologna, 1-383.

Ros RM, Mazimpaka V, Abou-Salama U, Aleffi M, Blockeel TL, Brugués M, Cros RM, Dia MG, Dirkse GM, Draper I, El-Saadawi W, Erdag A, Ganeva A, Gabriel R, González-Mancebo JM, Granger C, Herrnstadt I, Hugonnot V, Khalil K, Kürschner H, Losada-Lima A, Luís L, Mifsud S, Privitera M, Puglisi M, Sabovljevic M, Sérgio C, Shabbara HM, Sim-Sim M, Sotiaux A, Tacchi R, Vanderpoorten A, Werner O (2013) Mosses of the Mediterranean: an annotated checklist. Cryptogamie, Bryologie 34(2): 99-283. https://doi.org/10.7872/cryb.v34.iss2.2013.99

Schumacker R, Vána J (2005) Identification Keys to the Liverworts and Hornworts of Europe and Macaronesia (Distribution and Status). Sorus, Poznan, 209 pp.

Ubaldi D, Puppi G, Zanotti AL (1996) Carta Fitoclimatica dell'Emilia-Romagna con carta 1:500.000. Regione Emilia-Romagna, Bologna, 80 pp. 